\title{
Retentive force comparison between esthetic and metal clasps for removable partial denture
}

\author{
Comparação da força retentiva entre grampos estéticos e metálicos para prótese parcial removível
}

Eron Toshio Colauto YAMAMOTO ${ }^{1}$, Tabata Prado SATO², João Mauricio Ferraz da SILVA ${ }^{2}$, Alexandre Luiz Souto BORGES ${ }^{2}$, Eduardo Shigueyuki UEMURA ${ }^{2}$

1 - Department of Prosthodontics - Universidade Nove de Julho Dental School - Sao Paulo - SP - Brazil.

2 - São Paulo State University (Unesp) - Institute of Science and Technology - São José dos Campos - Department of Dental Materials and Prosthodontics - SP - Brazil.

\begin{abstract}
Objective: This study aimed to evaluate the retention of acetate resin clasp as when compared to metal clasp. Material and methods: For this purpose, we constructed 10 conventional Co-Cr metal clasps (Ackers) and 20 acetate resin clasps. The acetate resin clasps had the opposition, support and retaining arms made of Co-Cr. Of the 20 esthetic clasps, 10 had the thickness of the retention arm decreased to make it more esthetic. The initial retentive force of the specimens was tested in a universal testing machine through tensile test. After that, the specimens were subjected to 7,000 cycles, each one, in an adapted machine, immersed into artificial saliva, for 36 months of simulated clinical use of a removable partial denture. Data were tabulated for statistical analysis of the retention effectiveness. Results: After cycling, 3-mm-thick and 2-mmthick acetate resin clasps lost more retention than metal clasps. The material type $(\mathrm{p}=0.0000)$ and cycling $(\mathrm{p}=0.0039)$ showed a significant effect, but the material/cycling interaction $(p=0.1436)$ did not. Conclusions: Therefore, esthetic clasps presented retention force lower than that of metal clasps. Notwithstanding, the esthetic clasps can be used in clinical cases requiring minimum retention.
\end{abstract}

\section{KEYWORDS}

Removable partial denture; Esthetic clasp; Metal clasp.

\section{RESUMO}

Objetivo: Este estudo teve como objetivo avaliar a retenção do grampo de resina de acetato quando comparado ao grampo metálico. Material e métodos: Para isso, 10 grampos metálicos $\mathrm{Co}-\mathrm{Cr}$ convencionais (Ackers) e 20 de resina de acetate foram confeccionados. Os grampos de resina de acetato foram constituídos por braços de oposição, suporte e retenção feitos de CoCr. Dos 20 grampos estéticos, 10 tiveram a espessura do braço de retenção diminuídos para torná-los mais estéticos. A força de retenção inicial dos espécimes foi testada em uma máquina de teste universal através de teste de tração. Depois disso, os espécimes foram submetidos a 7.000 ciclos, cada um, em uma máquina adaptada, imersos em saliva artificial, por 36 meses, simulando uso clínico de uma prótese parcial removível. Os dados foram tabulados para análise estatística da eficácia de retenção. Resultados: Após ciclagem, os grampos de resina de acetato de $3 \mathrm{~mm}$ de espessura e $2 \mathrm{~mm}$ de espessura perderam mais retenção do que os grampos metálicos. O tipo de material $(\mathrm{p}=0,0000)$ e a ciclagem ( $p=0,0039)$ mostraram um efeito significativo, mas a interação material / ciclagem (p $=0,1436$ ) não. Conclusões: Portanto, os grampos estéticos apresentaram força de retenção inferior à dos grampus metálicos. No entanto, os grampos estéticos podem ser utilizados em casos clínicos que requerem retenção mínima.

\section{PALAVRAS-CHAVE}

Prótese parcial removível; Grampo estético; Grampo metálico. 


\section{INTRODUCTION}

$\mathrm{O}$ ral rehabilitation is very important for the individual's masticatory, phonetic and aesthetic functions, because those significantly affects the quality of life [1,2]. Despite of the advocated performance and success rates of fixed partial dentures (FPD), removable partial dentures (RPD) are still used for oral rehabilitation. The extension of the edentulous space, bone loss, short clinical crowns or financial conditions may account for other forms of rehabilitation such as RPD [3-5], used for years for the stomatognathic system restoration. Recent studies on prosthetic restorations illustrate the value of RPD design for a satisfactory use with good retention, stress distribution and aesthetic performance [6-8].

The major factor for RPD success is the retention $[9,10]$. The mechanical properties of RPD retainers knowing, clasps, depend on the materials composition as: titanium, gold, nickel/chromium and cobalt-chromium (Co$\mathrm{Cr}$ ) alloys $[11,12]$. In fact, Co-Cr alloys presents advantages in comparison to noble metal alloys as they have mechanical properties like flexibility [11], corrosion resistance, lighter weight, and higher cost effectiveness [13,14].

However, Co-Cr alloys have few drawbacks as failure of retaining arms under stress, frequency of repairs and esthetics [1518]. The components of the prosthesis should be, whenever possible, discreet to improve the RPD esthetics [16]. The poor esthetic of CoCr clasps lead the search for thermoplastic resin clasps to overcome this problem. Accordingly, Polyoxymethylene (POM), also known as acetal, has been used for the construction of RPD retaining and supporting components $[19,20]$.

$\mathrm{POM}$ is formed by polymerizing formaldehyde [21]. The homopolymer POM is a chain of alternating methyl groups linked to an oxygen molecule. In this sense, as a homopolymer, POM has good mechanical properties; also, as a copolymer, POM has longterm stability $[22,23]$.

One of the mostcritical requirements of RPD is the balance between strength and flexibility distribution, retention and reciprocity [24]. It is known that during RPD insertion and removal, the clamps suffer permanent deformation when exposed to repeated forces, reducing the retention and stability of the prosthesis [25-27]. To reduce clamp deformation, new materials, chemical and thermal treatments of the material and clasp design have been developed [28-30].

On one hand, RPD satisfactorily reestablish the masticatory and phonetics. On the other hand, the esthetics is mostly impaired by the positioning of retaining metal arms on the labial area. To our knowledge, the literature is scarce on studies on RPD esthetic clasps. Thus, this study aimed to compare the retention force between acetate resin and metal clasps.

\section{MATERIAL AND METHODS}

In this present study, the clasps were made of Acetate resin (Dental D Acetal Resin Quattroti - RoveloPorro - Italy) and CoCr alloy (Fit Flex - Talmax - Curitiba - Brazil).

A silicone impression was taken from a pre-molar tooth and a wax template of the tooth and a base was obtained. The base was perpendicular to the clasps' insertion path. On this wax template, the occlusal rest was performed on the distal side and the guiding plans on distal and lingual surfaces.

This wax template was sent to the laboratory for obtaining the $\mathrm{Co}-\mathrm{Cr}$ tooth template (Figure 1A and $1 \mathrm{~B}$ ). On this metal tooth template, 10 conventional Co-Cr clasps (Figure 2) (Ackers) and 20 resin acetate clasps with support, opposition and retaining arms made of Co-Cr were constructed in the laboratory.

Of the 20 esthetic clasps, 10 clasps 10 had the thickness of their retention arm decreased to 
improve the esthetic, resulting in 2-mm-thick and 3-mm-thick acetate clasps (Figure 3).

All clasps had a metal rod attached to the support arm according to the insertion path. This aimed to fasten the clasps during both the cycling period and the tensile test.
Before cycling, the retentive initial force of specimens was performed through tensile test, in a universal testing machine (DL-1000, EMIC, São José dos Pinhais, Brazil; $1 \mathrm{~mm} / \mathrm{min}$ ).

Then, the specimens were subjected to 7,000 cycles, in a customized machine [31],
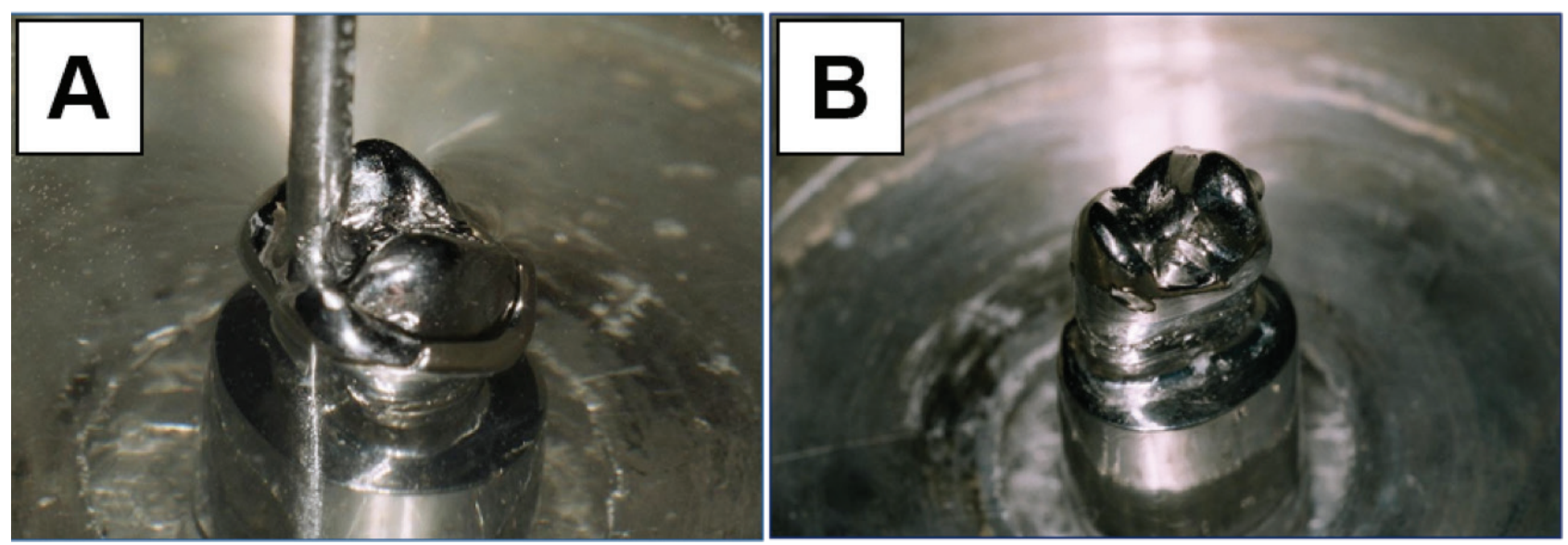

Figure 1 - Representation of metallic pattern (A) and guide plans (B).

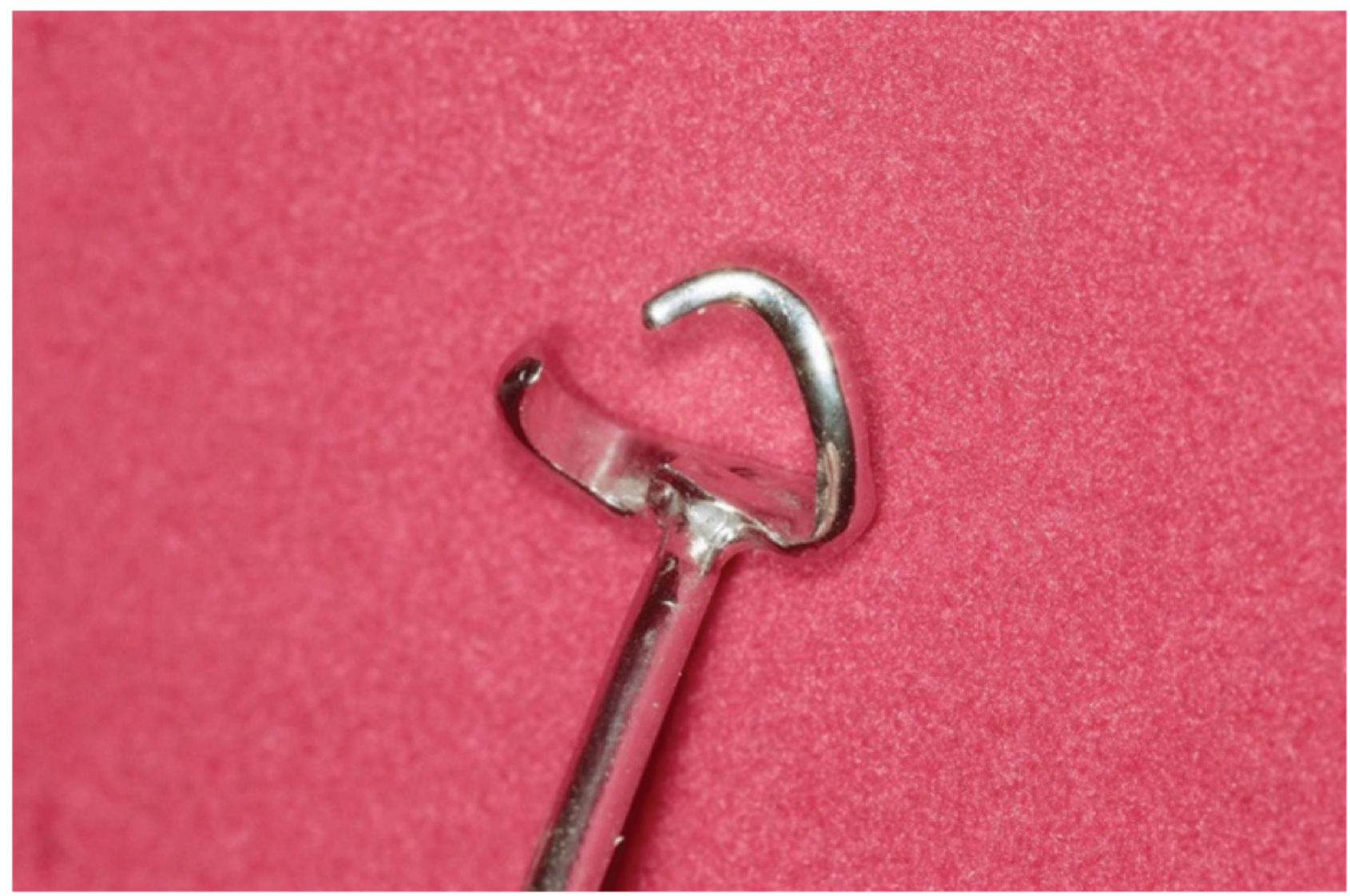

Figure 2 - Metallic clasp. 

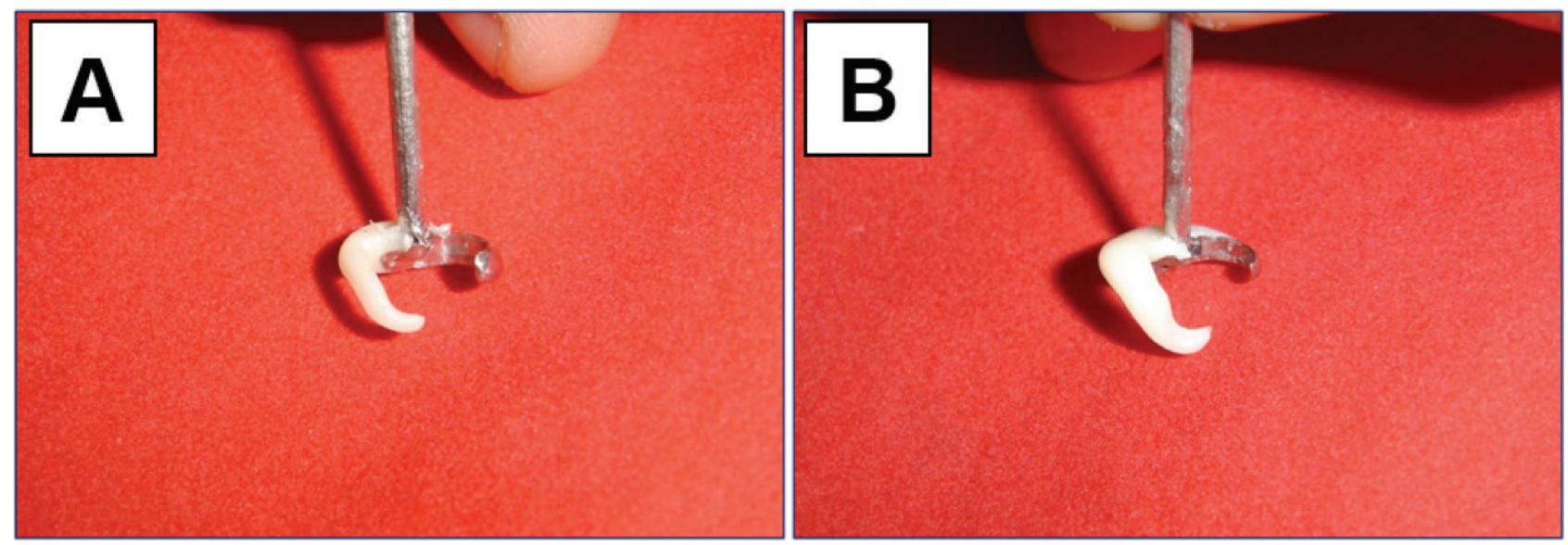

Figure 3 - Aesthetic Clasp (A) and Aesthetic decreased thickness (B).

immersed into artificial saliva, specially designed for the clasps insertion and removal, for 36 months of simulated clinical use of a removable partial denture. Next, the specimens were again submitted to the tensile test, to obtain the clasps retention values after cycling.

\section{Statistical analysis}

Descriptive statistical analysis was composed of mean and standard deviations values for the initial and final retentive forces and the percentage of retention loss to two independent variable (material and cycling). The data obtained were analyzed by two-way ANOVA with post-hoc Tukey. The level of statistically significance was set at $5 \%$.

\section{RESULTS}

The two-way ANOVA test showed statistically difference to Material $(\mathrm{p}<0.000)$ and Cycling $(\mathrm{p}=0.003)$ but not to interaction $(p=0.143)$.The comparison between the initial and final (after cycling) retention showed that 3-mm-thick acetate clasps had values of retention loss (61.43\%) higher than that of 2-mm-thick acetate clasps $(5,90 \%)$ and metallic clasps (26.5\%), which remained within a satisfactory value (Table 1 ). Both esthetic clasps showed initial and final values of resistance to removal lower than those of metal clasps.
Table 1 - Means (MPa), Standard Deviations (SD) and Tukey test (Same upper case letter and Capital Letter means, no statistical difference among groups).

\begin{tabular}{|c|c|c|c|c|}
\hline Material & Cycling & \multicolumn{2}{|c|}{ Retention } & Retention \\
\hline Aesthetic & $\begin{array}{l}\text { without* }^{\star} \\
\text { With }^{\star \star}\end{array}$ & $\begin{array}{c}0.60 \pm 0.38 \\
A\end{array}$ & $\begin{array}{c}0.86 \pm 0.44 \\
A B \\
0.33 \pm 0.19 A\end{array}$ & $61.43 \%$ \\
\hline $\begin{array}{l}\text { Aesthetic } \\
\text { decreased } \\
\text { thickness }\end{array}$ & $\begin{array}{l}\text { without }^{\star} \\
\text { With }^{\star \star}\end{array}$ & $\begin{array}{c}0.42 \pm 0.19 \\
\text { A }\end{array}$ & $\begin{array}{l}0.43 \pm 0.14 \mathrm{~A} \\
0.40 \pm 0.13 \mathrm{~A}\end{array}$ & $5.90 \%$ \\
\hline Metalic & $\begin{array}{l}\text { without }^{\star} \\
\text { With }^{\star \star}\end{array}$ & $\begin{array}{c}1.48 \pm 0.57 \\
\text { B }\end{array}$ & $\begin{array}{c}1.71 \pm 0.72 C \\
1.25 \pm 0.57 \\
\text { BC }\end{array}$ & $26.5 \%$ \\
\hline
\end{tabular}

Data were tabulated for statistical analysis of the retention effectiveness. The material type $(\mathrm{p}=0.0000)$ and the cycling $(\mathrm{p}=0.0039)$ showed a significant effect, but the material/ cycling interaction $(p=0.1436)$ did not.

\section{DISCUSSION}

RPD requires that a flexible clasp and a rigid framework $[32,33]$. The results of this present study demonstrated that after cycling, 3-mm-thick and 2-mm-thick acetate resin clasps lost more retention than metal clasps. The retention effectiveness showed that the cycling and material played a role in these results, without material/cycling interaction. 
After cycling, the 3-mm-thick acetate resin clasps lost $61.43 \%$ of retention (from 0.869 to $0.335 \mathrm{kgf}$ ). Although metal clasps lost $26.5 \%$ of retention (from 1.71 to $1.25 \mathrm{kgf}$ ), this value was within an acceptable range. The literature corroborates the findings of this present study. Arda and Arikan conducted an in vitro comparison of the retentive force and the deformation of the acetate resin and Co-Cr clasps. After 36 months of simulated clinical use, Co-Cr clasps showed evident deformation, but acetate resin clasps did not. However, the retentive resistance values and the mean dislodgement force of acetate resin clasps were lower than that of CoCr clamps. POM clasp flexibility would allow for the retainer to be placed in deeper occlusal rests on the abutment teeth [19]. Moreover, Tannous et al. showed that although thermoplastic resin clasps exhibited retention lower than that of CoCr clasps after insertion/removal cycles, the retention of adequately designed resin clasps might be sufficient for clinical use [34-36]. Jiao et al. [37] studied RPD stress distribution on the support teeth with different clasp and framework compositions (Co-Cr or Acetate) and found the best results with the conventional design (metal frame and clasps). These authors found that the RPD mixed design (Cr-Co framework, support and opposition arms + acetate resin clasps) exhibited stress distribution lower than that of RPD acetate design.

In this present study, however 3-mmthick acetate clasps showed higher deformation than 2-mm-thick acetate clasps, but without statistically significant differences.

The more flexibility of the 2-mm-thick acetate clasps led to a lower retention, but it enabled less deformation of the clasp. Arda and Arikan, found no clasp deformation because not only the support arm flexed, but the entire clasp, leading to a result better than that of this present study [19]. However, under a biomechanical point of view, the acetate opposition arm will not perform the reciprocal function and may cause a lever movement on the abutment teeth.
Also, the acetate opposition arm will not aid in the latero-lateral stability of the prosthesis.

The use of acetate in the support arm may increase the risk of fracture of this of the structure and it may put the prosthesis at the risk of intrusion because of acetate flexibility.

Thus, in this study, we use a metallic opposition arm. However, this led to more deformation in acetate retaining arm during insertion and removal of the clasp. Accordingly, the thinner the acetate retaining arm, the lower was the deformation because the 2-mm-thick acetate clasp was more flexible and less retentive.

\section{CONCLUSION}

Esthetic clasps were less retentive than metal clasps. Although Cr-Co clasp was more retentive, acetate resin clasp may be a solution for using in esthetics areas, in which minimal retention is required.

\section{REFERENCES}

1. John MT, Reissmann DR, Čelebić A, Baba K, Kende D, Larsson P, et al. Integration of oral health-related quality of life instruments. J Dent. 2016 0ct;53:38-43. doi: 10.1016/j.jdent.2016.06.006. Epub 2016 Jun 25.

2. Moldovan 0 , Rudolph $\mathrm{H}$, Luthardt RG. Clinical performance of removable dental prostheses in the moderately reduced dentition: a systematic literature review. Clin Oral Investig. 2016 Sep;20(7):143547. doi: 10.1007/s00784-016-1873-5. Epub 2016 Jun 9.

3. Chandler JA, Brudvik JS. Clinical evaluation of patients eight to nine years after placement of removable partial dentures. $J$ Prosthet Dent. 1984 Jun;51(6):736-43.

4. McKenna G, Tada S, Woods N, Hayes M, DaMata C, Allen PF. Tooth replacement for partially dentate elders: a willingness-to-pay analysis. J Dent. 2016 0ct;53:51-6. doi: 10.1016/j.jdent.2016.07.006. Epub 2016 Jul 13.

5. Mericske-Stern R. Removable partial dentures. Int J Prosthodont. 2009 Sep-0ct;22(5):508-11.

6. Jum'ah A, Haite T, Nattress B. The Windowed Removable Partial Denture: A Treatment Option for Patients with Lone-Standing Teeth. Eur J Prosthodont Restor Dent. 2015 Mar;23(1):40-5.

7. Pellizzer EP, Ferraço R, Tonella BP, Oliveira BJdC, Souza FL, Falcón-Antenucci RM. Influence of ridge type on mandibular distal extension removable partial denture. Acta Odontol Latinoam. 2010;23(1):68-73

8. Júnior MM, Anchieta RB, Rocha EP, Pereira JA, Archangelo CM, Freitas-Júnior $\mathrm{AC}$, et al. The influence of the alveolar ridge shape on the stress distribution in a free-end saddle removable 
partial denture supported by implant. Acta 0dontol Latinoam. 2011;24(2):168-75.

9. Sailer I, Makarov NA, Thoma DS, Zwahlen M, Pjetursson BE. Allceramic or metal-ceramic tooth-supported fixed dental prostheses (FDPs)? A systematic review of the survival and complication rates. Part I: Single crowns (SCs). Dent Mater. 2015 Jun;31(6):60323. doi: 10.1016/j.dental.2015.02.011. Epub 2015 Apr 2.

10. Pommer B, Hingsammer L, Haas R, Mailath-Pokorny G, Busenlechner D, Watzek G, et al. Denture-Related Biomechanical Factors for Fixed Partial Dentures Retained on Short Dental Implants. Int J Prosthodont. 2015 Jul-Aug;28(4):412-4. doi: 10.11607/ ijp.4238.

11. Reddy JC, Chintapatla SB, Srikakula NK, Juturu RKR, Paidi SK, Tedlapu SK, et al. Comparison of Retention of Clasps Made of Different Materials Using Three-Dimensional Finite Element Analysis. J Clin Diagn Res. 2016 May;10(5):ZC13-6. doi: 10.7860/ JCDR/2016/18405.7731. Epub 2016 May 1.

12. Vallittu PK, Kokkonen M. Deflection fatigue of cobalt-chromium, titanium, and gold alloy cast denture clasp. J Prosthet Dent. 1995 0ct;74(4):412-9.

13. Carek A, Živko-Babić J, Schauperl Z, Jakovac M. Macroscopic analysis of $\mathrm{Co}-\mathrm{Cr}$ base alloys joints. Acta Stomatol Croat. 2007;41(3):216-24.

14. Crook P, Asphahani Al, Matthews SJ, inventores; Haynes International. Corrosion-and-wear-resistant cobalt-base alloy. US 5002731. 1991 Mar 26.

15. Belles DM. The Twin-Flex clasp: an esthetic alternative. J Prosthet Dent. 1997 Apr;77(4):450-2.

16. Beaumont Jr AJ. An overview of esthetics with removable partial dentures. Quintessence Int. 2002 Nov-Dec;33(10):747-55.

17. Donovan TE, Cho GC. Esthetic considerations with removable partial dentures. J Calif Dent Assoc. 2003 Jul;31(7):551-7.

18. Jiao T, Chang T, Caputo A. Load transfer characteristics of unilateral distal extension removable partial dentures with polyacetal resin supporting components. Aust Dent J. 2009 Mar;54(1):31-7. doi: 10.1111/j.1834-7819.2008.01085.x.

19. Arda T, Arikan A. An in vitro comparison of retentive force and deformation of acetal resin and cobalt-chromium clasps. J Prosthet Dent. 2005 Sep;94(3):267-74.

20. Chu C, Chow T. Esthetic designs of removable partial dentures. Gen Dent. 2003 Jul-Aug;51(4):322-4.

21. Kern W, Deibig H, Giefer A, Jaacks V. Polymerization and copolymerization of trioxan. Pure Appl Chem. 1966;12(1-4):371-86.

22. Archodoulaki V-M, LüftI S, Koch T, Seidler S. Property changes in polyoxymethylene (POM) resulting from processing, ageing and recycling. Polym Degrad Stab. 2007;92(12):2181-9.
23. Penick KJ, Solchaga LA, Berilla JA, Welter JF. Performance of polyoxymethylene plastic (POM) as a component of a tissue engineering bioreactor. J Biomed Mater Res A. 2005 0ct 1;75(1):168-74

24. McGivney G, Castleberry D. McCracken's removable partial prosthodontics. 8 ed. St Louis: CV Mosby; 1989.

25. Hofmann E, Behr M, Handel G. Frequency and costs of technical failures of clasp-and double crown-retained removable partial dentures. Clin Oral Investig. 2002 Jun;6(2):104-8.

26. Saito M, Notani K, Miura Y, Kawasaki T. Complications and failures in removable partial dentures: a clinical evaluation. J Oral Rehabil. 2002 Jul;29(7):627-33.

27. Wiskott HW, Nicholls JI, Belser UC. Stress fatigue: Basic principles and prosthodontic implications. Int J Prosthodont. 1995 MarApr;8(2):105-16.

28. Lin CW, Ju CP, Chern Lin JH. A comparison of the fatigue behavior of cast $\mathrm{Ti}-7.5 \mathrm{Mo}$ with c.p. titanium, $\mathrm{Ti}-6 \mathrm{Al}-4 \mathrm{~V}$ and $\mathrm{Ti}-13 \mathrm{Nb}-13 \mathrm{Zr}$ alloys. Biomaterials. 2005 Jun;26(16):2899-907.

29. Yuasa Y, Sato Y, Ohkawa S, Nagasawa T, Tsuru H. Finite element analysis of the relationship between clasp dimensions and flexibility. J Dent Res. 1990;69(10):1664-8.

30. Sato Y, Shindoi N, Koretake K, Hosokawa R. The effect of occlusal rest size and shape on yield strength. J Prosthet Dent. 2003 May;89(5):503-7.

31. Saavadra G, Barbosa SH, Landin KT, Alonso AA, Vasconcelos DK, Avelar RP, et al. Influência do ângulo de inserçao na degradaçao da retençao do 0-ring em overdenture. Implant News. 2007:4(3):24953.

32. Krol AJ. Clasp design for extension-base removable partial dentures. J Prosthet Dent. 1973 Apr;29(4):408-15.

33. Jacobson TE, Krol AJ. Rotational path removable partial denture design. J Prosthet Dent. 1982 0ct;48(4):370-6.

34. Tannous F, Steiner M, Shahin R, Kern M. Retentive forces and fatigue resistance of thermoplastic resin clasps. Dent Mater. 2012 Mar;28(3):273-8. doi: 10.1016/j.dental.2011.10.016. Epub 2011 Nov 29.

35. Savitha P, Lekha K, Nadiger RK. Fatigue resistance and flexural behavior of acetal resin and chrome cobalt removable partial denture clasp: An in vitro study. Eur J Prosthodont Restor Dent. 2015;3(3):71-6.

36. Turner JW, Radford DR, Sherriff M. Flexural properties and surface finishing of acetal resin denture clasps. J Prosthodont. 1999 Sep;8(3):188-95.

37. Jiao T, Chang T, Caputo A. Load transfer characteristics of unilateral distal extension removable partial dentures with polyacetal resin supporting components. Aust Dent J. 2009 Mar;54(1):31-7. doi: 10.1111/j.1834-7819.2008.01085.x.

\section{Tabata Prado Sato} (Corresponding address)

Av. Dr. Eng.Francisco Jose Longo, 777, Jd. Sao Dimas

Sao Jose dos Campos, Brazil

Date submitted: 2017 Apr 24

Email: tabata.sato@ict.unesp.br 